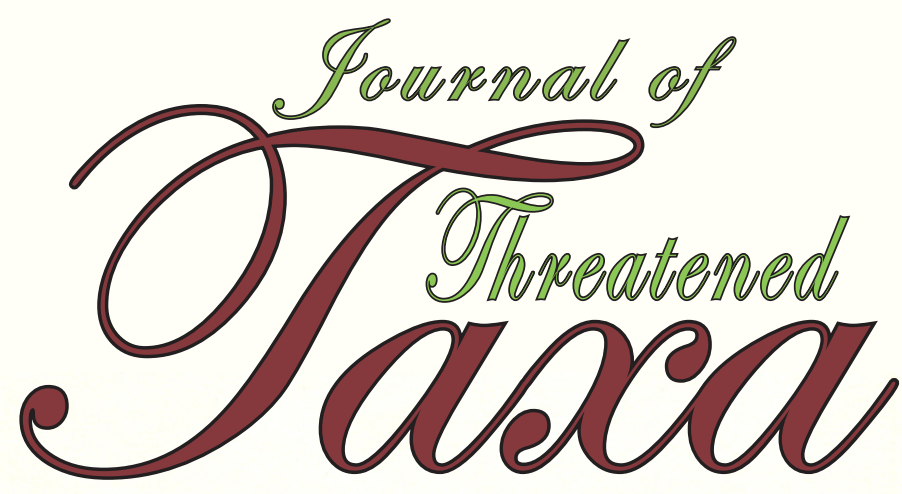

10.11609/jott.2021.13.14.20143-20310 enever.threatenedtaxa.org

26 December 2021 (Online \& Print) Val. 13 | Na. 14 | Pages: 20143-20310 155n 0974-7907 (Online) 155n 0974-7893 (Print)

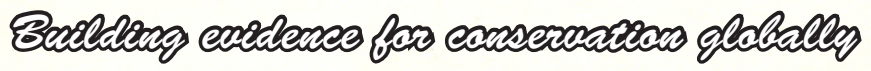

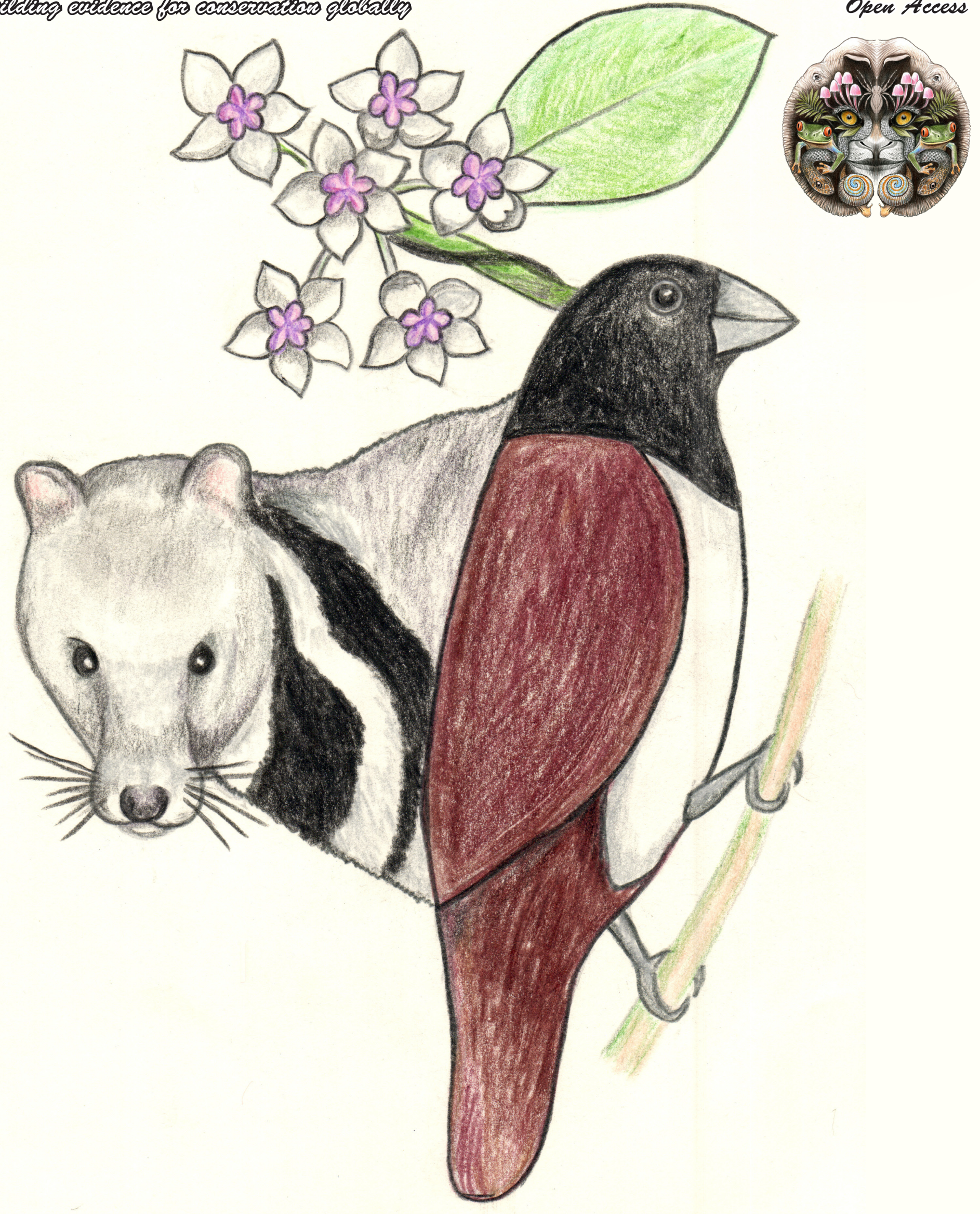

Open Access 


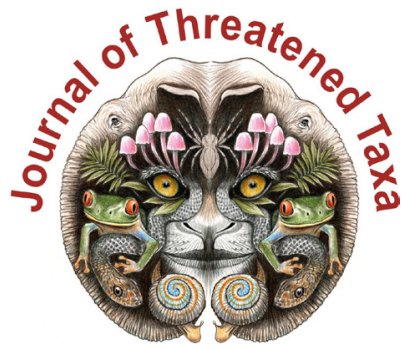

ISSN 0974-7907 (Online); ISSN $0974-7893$ (Print)

Publisher

Host

Wildlife Information Liaison Development Society

www.wild.zooreach.org

Zoo Outreach Organization www.zooreach.org

No. 12, Thiruvannamalai Nagar, Saravanampatti - Kalapatti Road, Saravanampatti, Coimbatore, Tamil Nadu 641035, India

Ph: +91 9385339863 | www.threatenedtaxa.org

Email: sanjay@threatenedtaxa.org

EDITORS

\section{Founder \& Chief Editor}

Dr. Sanjay Molur

Wildlife Information Liaison Development (WILD) Society \& Zoo Outreach Organization (ZOO),

12 Thiruvannamalai Nagar, Saravanampatti, Coimbatore, Tamil Nadu 641035, India

\section{Deputy Chief Editor}

Dr. Neelesh Dahanukar

Noida, Uttar Pradesh, India

\section{Managing Editor}

Mr. B. Ravichandran, WILD/ZOO, Coimbatore, India

\section{Associate Editors}

Dr. Mandar Paingankar, Government Science College Gadchiroli, Maharashtra 442605, India

Dr. Ulrike Streicher, Wildlife Veterinarian, Eugene, Oregon, USA

Ms. Priyanka lyer, ZOO/WILD, Coimbatore, Tamil Nadu 641035, India

Dr. BA. Daniel, $200 / \mathrm{WILD}$, Coimbatore, Tamil Nadu 641035, India

\section{Editorial Board}

Dr. Russel Mittermeie

Executive Vice Chair, Conservation International, Arlington, Virginia 22202, USA

\section{Prof. Mewa Singh Ph.D., FASc, FNA, FNASc, FNAPsy}

Ramanna Fellow and Life-Long Distinguished Professor, Biopsychology Laboratory, and Institute of Excellence, University of Mysore, Mysuru, Karnataka 570006, India; Honorary Professor, Jawaharlal Nehru Centre for Advanced Scientific Research, Bangalore; and Adjunct Professor, National Institute of Advanced Studies, Bangalore

\section{Stephen D. Nash}

Scientific Illustrator, Conservation International, Dept. of Anatomical Sciences, Health Sciences Center, T-8, Room 045, Stony Brook University, Stony Brook, NY 11794-8081, USA

\section{Dr. Fred Pluthero}

Toronto, Canada

\section{Dr. Priya Davidar}

Sigur Nature Trust, Chadapatti, Mavinhalla PO, Nilgiris, Tamil Nadu 643223, India

\section{Dr. Martin Fisher}

Senior Associate Professor, Battcock Centre for Experimental Astrophysics, Cavendish

Laboratory, JJ Thomson Avenue, Cambridge CB3 OHE, UK

\section{Dr. John Fellowes}

Honorary Assistant Professor, The Kadoorie Institute, 8/F, T.T. Tsui Building, The University of Hong Kong, Pokfulam Road, Hong Kong

\section{Prof. Dr. Mirco Solé}

Universidade Estadual de Santa Cruz, Departamento de Ciências Biológicas, Vice-coordenado do Programa de Pós-Graduação em Zoologia, Rodovia Ilhéus/Itabuna, Km 16 (45662-000)

Salobrinho, Ilhéus - Bahia - Brasil

\section{Dr. Rajeev Raghavan}

Professor of Taxonomy, Kerala University of Fisheries \& Ocean Studies, Kochi, Kerala, India

\section{English Editors}

Mrs. Mira Bhojwani, Pune, India

Dr. Fred Pluthero, Toronto, Canad

Mr. P. Ilangovan, Chennai, India

Web Development

Mrs. Latha G. Ravikumar, ZOO/WILD, Coimbatore, India

\section{Typesetting}

Mr. Arul Jagadish, ZOO, Coimbatore, India

Mrs. Radhika, ZOO, Coimbatore, India

Mrs. Geetha, ZOO, Coimbatore India
Fundraising/Communications

Mrs. Payal B. Molur, Coimbatore, India

Subject Editors 2018-2020

Fungi

Dr. B. Shivaraju, Bengaluru, Karnataka, India

Dr. R.K. Verma, Tropical Forest Research Institute, Jabalpur, India

Dr. Vatsavaya S. Raju, Kakatiay University, Warangal, Andhra Pradesh, India

Dr. M. Krishnappa, Jnana Sahyadri, Kuvempu University, Shimoga, Karnataka, India

Dr. K.R. Sridhar, Mangalore University, Mangalagangotri, Mangalore, Karnataka, India

Dr. Gunjan Biswas, Vidyasagar University, Midnapore, West Bengal, India

\section{Plants}

Dr. G.P. Sinha, Botanical Survey of India, Allahabad, India

Dr. N.P. Balakrishnan, Ret. Joint Director, BSI, Coimbatore, India

Dr. Shonil Bhagwat, Open University and University of Oxford, UK

Prof. D.J. Bhat, Retd. Professor, Goa University, Goa, India

Dr. Ferdinando Boero, Università del Salento, Lecce, Italy

Dr. Dale R. Calder, Royal Ontaro Museum, Toronto, Ontario, Canada

Dr. Cleofas Cervancia, Univ. of Philippines Los Baños College Laguna, Philippines

Dr. F.B. Vincent Florens, University of Mauritius, Mauritius

Dr. Merlin Franco, Curtin University, Malaysia

Dr. V. Irudayaraj, St. Xavier's College, Palayamkottai, Tamil Nadu, India

Dr. B.S. Kholia, Botanical Survey of India, Gangtok, Sikkim, India

Dr. Pankaj Kumar, Kadoorie Farm and Botanic Garden Corporation, Hong Kong S.A.R., China

Dr. V. Sampath Kumar, Botanical Survey of India, Howrah, West Bengal, India

Dr. A.J. Solomon Raju, Andhra University, Visakhapatnam, India

Dr. Vijayasankar Raman, University of Mississippi, USA

Dr. B. Ravi Prasad Rao, Sri Krishnadevaraya University, Anantpur, India

Dr. K. Ravikumar, FRLHT, Bengaluru, Karnataka, India

Dr. Aparna Watve, Pune, Maharashtra, India

Dr. Qiang Liu, Xishuangbanna Tropical Botanical Garden, Yunnan, China

Dr. Noor Azhar Mohamed Shazili, Universiti Malaysia Terengganu, Kuala Terengganu, Malaysia

Dr. M.K. Vasudeva Rao, Shiv Ranjani Housing Society, Pune, Maharashtra, India

Prof. A.J. Solomon Raju, Andhra University, Visakhapatnam, India

Dr. Mandar Datar, Agharkar Research Institute, Pune, Maharashtra, India

Dr. M.K. Janarthanam, Goa University, Goa, India

Dr. K. Karthigeyan, Botanical Survey of India, India

Dr. Errol Vela, University of Montpellier, Montpellier, France

Dr. P. Lakshminarasimhan, Botanical Survey of India, Howrah, India

Dr. Larry R. Noblick, Montgomery Botanical Center, Miami, USA

Dr. K. Haridasan, Pallavur, Palakkad District, Kerala, India

Dr. Analinda Manila-Fajard, University of the Philippines Los Banos, Laguna, Philippines

Dr. P.A. Sinu, Central University of Kerala, Kasaragod, Kerala, India

Dr. Afroz Alam, Banasthali Vidyapith (accredited A grade by NAAC), Rajasthan, India

Dr. K.P. Rajesh, Zamorin's Guruvayurappan College, GA College PO, Kozhikode, Kerala, India

Dr. David E. Boufford, Harvard University Herbaria, Cambridge, MA 02138-2020, USA

Dr. Ritesh Kumar Choudhary, Agharkar Research Institute, Pune, Maharashtra, India

Dr. Navendu Page, Wildlife Institute of India, Chandrabani, Dehradun, Uttarakhand, India

\section{Invertebrates}

Dr. R.K. Avasthi, Rohtak University, Haryana, India

Dr. D.B. Bastawade, Maharashtra, India

Dr. Partha Pratim Bhattacharjee, Tripura University, Suryamaninagar, India

Dr. Kailash Chandra, Zoological Survey of India, Jabalpur, Madhya Pradesh, India

Dr. Ansie Dippenaar-Schoeman, University of Pretoria, Queenswood, South Africa

Dr. Rory Dow, National Museum of natural History Naturalis, The Netherlands

Dr. Brian Fisher, California Academy of Sciences, USA

Dr. Richard Gallon, llandudno, North Wales, LL30 1UP

Dr. Hemant V. Ghate, Modern College, Pune, India

Dr. M. Monwar Hossain, Jahangirnagar University, Dhaka, Bangladesh

Mr. Jatishwor Singh Irungbam, Biology Centre CAS, Branišovská, Czech Republic.

Dr. Ian J. Kitching, Natural History Museum, Cromwell Road, UK

Dr. George Mathew, Kerala Forest Research Institute, Peechi, India

For Focus, Scope, Aims, and Policies, visit https://threatenedtaxa.org/index.php/JoTT/aims_scope
For Article Submission Guidelines, visit https://threatenedtaxa.org/index.php/JoTT/about/submissions
For Policies against Scientific Misconduct, visit https://threatenedtaxa.org/index.php/JoTT/policies_various 


\title{
Roosting patterns of House Sparrow Passer domesticus Linn., 1758 (Aves: Passeridae) in Bhavnagar, Gujarat, India
}

\section{Foram P. Patel ${ }^{1}$ (1) \& Pravinsang P. Dodia ${ }^{2}$ (1)}

1,2 Department of Zoology, Sir P.P. Institute of Science, MKBU University, Bhavnagar, Gujarat 364002, India. ${ }^{1}$ patelforam9795@gmail.com, ${ }^{2}$ pravinsangdodia@gmail.com (corresponding author)

\begin{abstract}
The House Sparrow Passer domesticus is widely distributed across the world, and local alarming declines in sparrow populations have prompted studies focused on this species. An understanding of fundamental life history aspects such as roosting patterns is necessary for the development of efficient conservation strategies. This study examined House Sparrow roosting patterns in urban, suburban and rural areas of Bhavnagar during 2017-2018. Potential roosting sites were identified, and peak arrival/ departure times and roosting duration of sparrows were recorded. We found that peak arrival and departure times were correlated with solar timings, indicating a strong influence of photoperiod on sparrow behaviour. Little variation was observed in sparrow arrival and departure times across the urban, suburban and rural gradient. However, arrival duration was significantly larger in urban and suburban areas. This may be due to the restricted availability of suitable patches within these habitats, requiring birds to spend more time foraging. House Sparrows mostly preferred thick vegetation for pre-roosting activities and roosting, and the loss of thick vegetation poses a threat to sparrow populations worldwide. In addition to increasing nesting opportunities by providing artificial nest sites, the importance of retaining appropriate habitats should be a major focus of conservation strategies.
\end{abstract}

Keywords: Arrival \& departure pattern, habitat, nesting, Passeriformes, pre-roosting.

Citation: Patel, F.P. \& P.P. Dodia (2021).Roosting patterns of House Sparrow Passer domesticus Linn., 1758 (Aves: Passeridae) in Bhavnagar, Gujarat, India. Journal of Threatened Taxa 13(14): 20209-20217. https://doi.org/10.11609/jott.6631.13.14.20209-20217

Copyright: (c) Patel \& Dodia 2021. Creative Commons Attribution 4.0 International License. JoTT allows unrestricted use, reproduction, and distribution of this article in any medium by providing adequate credit to the author(s) and the source of publication.

Funding: None.

Competing interests: The authors declare no competing interests.

Author details: Currently, FORAM P. PATEL is working as an Assistant Professor at D K V Arts \& Science College Jamnagar, Gujarat. She has recently completed her doctorate from MKBU University, Bhavnagar, Gujarat. Her research work was focused on analyzing the impact of anthropogenic pressures on House Sparrow with reference to different scale of habitat in Bhavnagar, Gujarat. Her current works focuses on exploring avian diversity across different patches of Jamnagar, Gujarat. DR. PRAVINSANG P. DODIA is working as an Associate Professor at Sir P P Institute of Science, MKBU University, Bhavnagar, Gujarat. His keen interest is in avian biology.

Author contributions: FPP-conception \& design of the work, data collection, data analysis and interpretation, drafting the article. PPD-supervisor, critical revision of the article.

Acknowledgements: We would like to express our special thanks of gratitude to Dr. A H Shukla, head of Zoology Department, Sir P.P. Institute of Science, Bhavnagar, for his sincere support. Sincere thanks to P. Chudasama, D. Solanki, J. Kanejiya, D. Kunapara, D. Mehta, K. Tadha, D. Trivedi, K. Joshi, S. Gohel, J. Pandya, and Rajendra for assisting in field work. We would also like to thank Dr. N. Chavada who helped us in identification of plant species. 


\section{INTRODUCTION}

The House Sparrow Passer domesticus is one of the most widely distributed avian species on Earth, possibly due to its adaptation to human settlements. Nevertheless, significant declines in its populations have recently been reported from many parts of the world (Gulati 2005). These declines have prompted studies of sparrow breeding biology worldwide (Gokula et al. 2014). However, key habitat needs of the species will not end by finding suitable nest sites only. Understanding of other fundamental life history traits of the species such as the roosting pattern is inevitable, in constructing an efficient frame work for conservation of the species to maintain a healthy sustainable population.

Roosting can be defined as a period of inactivity analogous to human sleep (Ehrlich et al. 1988). Roosting is one of the fundamental life history traits of avian species. Small passerine birds such as sparrows roost communally, which confers many probable advantages as well as disadvantages to the birds. According to Ehrlich et al. (1988) some species change their roosting habits seasonally: male Red-winged Blackbirds Agelaius phoeniceus, normally roost solitarily on their territories during the breeding season, but roost in large numbers for the rest of the year. Communal roosting in avian populations probably helps in reducing the cost of thermoregulation and predation risk, and it is also likely to increase foraging efficiency of the individuals (Eiserer 1984; Ydenberg \& Prins 1984). According to Ward \& Zahavi (1973), roosting forms the centre to exchange information regarding food resources. However, Erwin (1983) opined that enhancement of food location takes place via local enhancement rather than by information exchanged at the roost. Besides, communal roost also provides potential mate selecting opportunities to birds lacking a partner. However, besides possible advantages, communal roost may be energetically costly to territorial species as they need to physically trave to and from roosts (Beauchamp 1999). Further, a large communal roost easily attracts potential predators due to significant vocalization (Beauchamp 1999). Thus, the significances of communal roosting are debatable (Richner \& Hebb 1996). The aforementioned studies, stress the importance of investigating the roosting ecology of birds.

In the present study, an attempt has been made to understand the roosting pattern of the sparrow across urban, suburban and rural gradient of Bhavnagar and to identify key habitat requirements of the species. By monitoring roosting patterns of sparrows across different scales of habitat will shed light on understanding corresponding key habitat requirements for healthy and efficient survival of the species. Consequently efficient strategic plans can be framed to fulfil key habitat requirements of the species with respect to its conservation aspects.

\section{Study area}

The present study was undertaken in and around Bhavnagar city, Saurashtra region of Gujarat state, India. Bhavnagar is a coastal city, with the Gulf of Khambhat located to its west. A small non perennial river known as Kansara passes through the outer area of the city. Bhavnagar has a hot semi arid climate, with a hot dry summer, wet monsoon, and mild winters. Due to the proximity of Bhavnagar to the gulf, the climate remains fairly humid throughout the year.

To identify differential response of the sparrow towards different scales of habitat, the study area was divided into three gradients, i.e., urban, suburban and rural. After a pilot survey, three potential roosting sites were selected from each gradient by random stratified method. To avoid biases in the data due to population mixture of different sample sites, it was ensured that the selected sample sites were at least $2 \mathrm{~km}$ apart from each other - by assuming the sedentary nature of sparrows not migrating more than $2 \mathrm{~km}$ (Summers - Smith 1988). This was accomplished by creating $2 \times 2 \mathrm{~km}$ grids over the study area with the help of Google earth pro software, where each sample site has been cited. Hence, nine study sites were selected to monitor roosting patterns and population of the sparrow throughout the study period. In the current study, within urban gradient (URB) - Barsomahadev (URB1) (21.774N,72.139E), Bharatnagar (URB2) (21.744N, 72.160E) and Anandnagar (URB3) (21.788N, 72.157E) study sites were selected for data collection. Within suburban gradient (SUB) $\checkmark$ P Society (SUB1) ( 21.759N, 72.170E), Forest colony (SUB2) $(21.737 \mathrm{~N}, 72.150 \mathrm{E})$ and Fulsar (SUB3) $(21.746 \mathrm{~N}$, 72.094E) study sites were selected for data collection. While within rural (RUR) - Akwada (RUR1) (21.739N, 72.180E), Nari (RUR2) (21.783N, 72.077E) and Sidsar (RUR3) $(21.721 \mathrm{~N}, 72.110 \mathrm{E})$ study sites were selected (Image 1). 


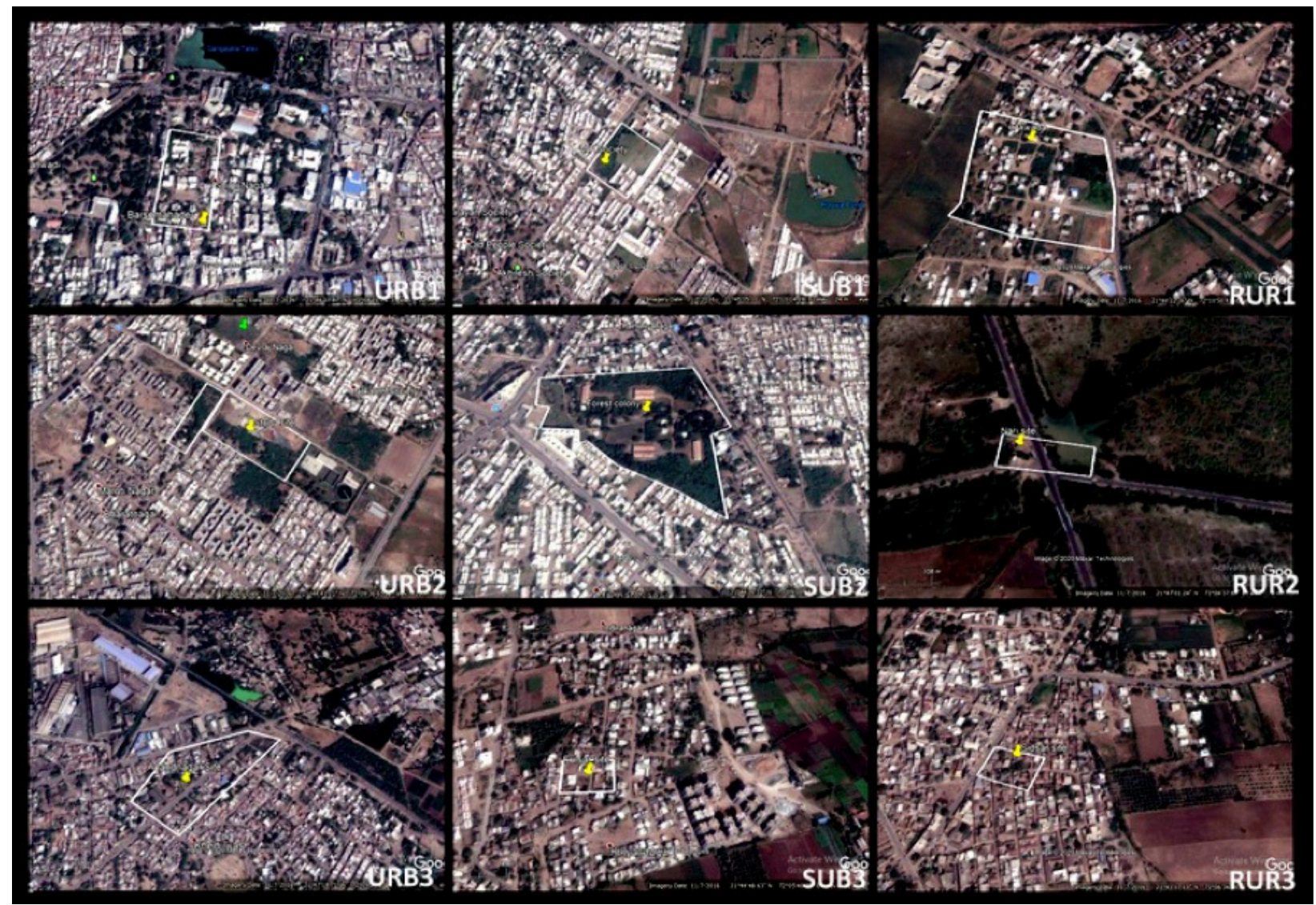

Image 1. Google Earth satellite image of Barsomahadev (URB1), Bharatnagar (URB2), Anandnagar (URB3), V P Society (SUB1), Forest colony (SUB2), Fulsar (SUB3), Akwada (RUR1), Nari (RUR2) and Sidsar (RUR3) study sites of Bhavnagar.

\section{METHODS}

The present study was conducted during the year December 2016 to November 2018 (24 months). For convenience, the study period was divided into four seasons, i.e., winter (December-February), summer (March-May), monsoon (June-August), and post monsoon (September-November). These categories aid in understanding seasonal variation in roosting patterns. For precise observation and data collection, instruments like Nikon Aculon A211 8 × 42 binocular and Nikon D500 digital SLR camera were used in the field.

In the year 2016, a pilot survey was carried out across the study area with the aim of identifying sites with a potential number of sparrows. Potential roosting sites were identified during the pilot survey by following flocks of sparrows from foraging grounds in the evening. The potential roosting sites were defined as places where more than a hundred sparrows were found to roost frequently during the pilot survey. Avian species, roosting together with sparrows at the same roosting plant were also recorded. During the study period, in some cases, sparrows left the original roosting site and preferred to roost at a different site - secondary roosting site. In these cases, locations of the secondary roosting place was determined by following the flock of sparrows from the original roosting site or from the foraging ground in the evening. The approximate distance of the secondary roosting site from the original roosting site was determined with the help of Google Earth pro software. Further, roosting plant species used by sparrows were identified with the help of standard field guides as well as experts in Botany. During this study, timings of roosting sounds were also recorded. Further, peak arrival and departure time periods along with arrival \& departure durations were recorded during each visit. Here all timings are represented in hh:mm (hour: minutes) format. Sunset and sunrise time was noted by IST (Indian standard time, off set: UTC + 5: 30) from time and date. com website (https://www.timeanddate.com/). To be more precise in finding the relationship between solar movement and arrival as well as departure pattern of House Sparrows from roosting sites, different phases of twilight timings were also considered during the study 
period. A total of three twilight timings were considered during this study, which included civil twilight (brightest phase of twilight - enough natural light to carry out most outdoor activities), nautical twilight (the horizon and the brighter stars are generally visible), and astronomical twilight (darkest phase of twilight).

\section{Statistical analysis}

Data was analyzed using IBM SPSS v.22.0 for Windows. Variance in peak arrival time, arrival duration, peak departure time, departure duration were analysed by gradients as well as by season using IndependentSamples Kruskal-Wallis Test - non parametric test. Spearman rank - order correlation coefficient test was used to correlate peak arrival and peak departure times with sunset, sun rise and day length respectively. Significance was set at $\mathrm{P}<0.05$ for all statistical tests. For each test, degrees of freedom (df) and significance levels are reported. All results are presented as mean \pm standard error (SE). All post hoc test results reported in compact letter display format in table as well as in chart, where groups are represented by superscript alphabetical letter. Groups with the same letter are statistically significantly similar and the others are statistically significantly different. Those groups, which are represented by more than one letter, are similar to groups represented by the same letter.

\section{RESULTS}

House Sparrows roost communally. Often large numbers of sparrows aggregate at night shelter and form a significant communal roost which can be easily identified from a distance by pronounced roosting vocalization of the sparrows. In the current study, Ziziphus xylopyrus, Ziziphus jujube, Prosopis Juliflora, Acasia Senegal, and Bambusa vulgaris were used as roosting plants by sparrows (Image 2). However, sparrows also used Punica granatum, Morus alba, Syzygium cumini, Ficus religiosa, and Banyan tree Ficus benghalensis for roosting purposes, often in the absence of the aforementioned roosting plant species (Table 1), sparrows often used empty nests for roosting purposes, i.e., roost nest (Image 3E). During the study, it was observed that roosting sparrows often visited or gathered at pre-roosting sites (other than roosting sites) before entering a roosting plant. Various maintenance activities such as sand baths, preening, rubbing bills and fluffing were observed during pre-roosting at all the sites (Image 3B). Sometimes collective motion (murmuration)
Table 1. List of different plant species used by House Sparrows for roosting during the study.

\begin{tabular}{|c|l|l|l|}
\hline \multicolumn{4}{|c|}{ Roosting plant species } \\
\hline & Scientific name & Common name & Family \\
\hline 1 & Ziziphus xylopyrus & Moti boradi & Rhamnaceae \\
\hline 2 & Ziziphus jujuba & Boradi & Rhamnaceae \\
\hline 3 & Prosopis Juliflora & Gando baval & Fabaceae \\
\hline 4 & Acasia Senegal & Gorad baval & Fabaceae \\
\hline 5 & Bambusa vulgaris & Vans & Poaceae \\
\hline 6 & Punica granatum & Dadam & Lythraceae \\
\hline 7 & Morus alba & Shetur & Moraceae \\
\hline 8 & Syzygium cumini & Jambu & Myrtaceae \\
\hline 9 & Ficus religiosa & Peepal tree & Moraceae \\
\hline 10 & Ficus benghalensis & Banyan tree & Moraceae \\
\hline
\end{tabular}

was observed during aggregation of large numbers of sparrows at roosting sites (Image $3 \mathrm{~A}$ ). Collective motion of sparrows was common at urban and suburban sites, mainly when a large aggregation of sparrows occurred during the post-breeding season.

No significant statistical difference was found in mean peak arrival time of sparrows across urban, suburban and rural roosting sites for both the years (Figure 1). Peak arrival time of sparrows at different roosting sites was strongly correlated with sunset time, which was statistically significant, $r_{s}(202)=0.848, p$ $<0.0001$ (Figure 2). Similarly, there was a strong positive correlation between peak arrival time and day length, which was also statistically significant, $r_{s}(202)=0.819$, $p<0.0001$ (Figure 3). During the observation, the peak numbers of House sparrows were recorded $0.5 \mathrm{~h}$ before sunset. House Sparrows arrived at roost sites in different flock size ranging 3-40. In 2017, there was a significant statistical difference in mean arrival duration across urban, suburban and rural gradients $(H(2)=16.99, p$ $<0.0001)$. The Bonferroni post hoc test revealed that mean arrival duration at rural gradient was statistically significantly lower than urban $(p<0.0001)$ and suburban gradient $(p<0.05)$. There was no statistically significant difference in mean arrival duration between suburban and urban gradient ( $p>0.05$ ) (Figure 4). Similarly, in 2018, there was a significant statistical difference in mean arrival duration across different gradient $(\mathrm{H}(2)=7.05, \mathrm{p}$ $<0.05)$. The Bonferroni post hoc test revealed that mean arrival duration at suburban gradient was statistically significantly higher than urban gradient $(p<0.05)$. There was no significant statistical difference in mean arrival duration between urban - rural gradients and rural - 


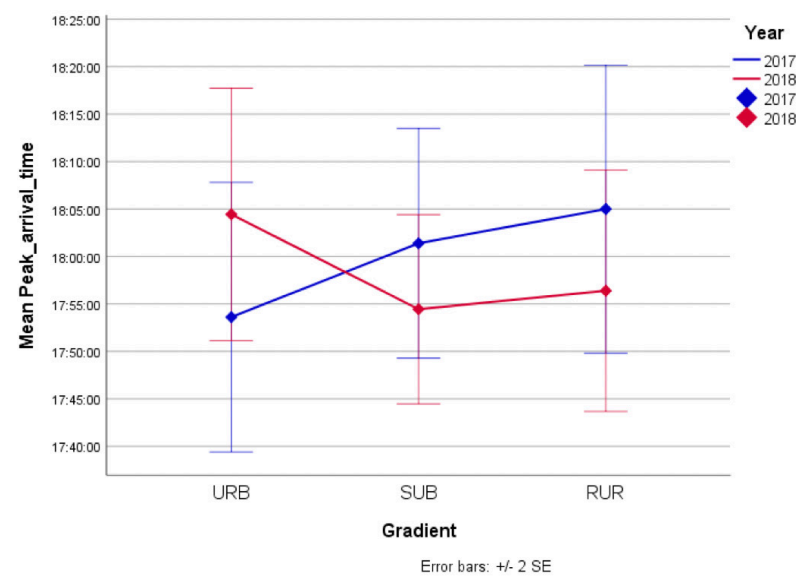

Figure 1. The mean peak arrival time of House Sparrow at different roosting sites across urban (URB), suburban (SUB), and rural (RUR) gradients of Bhavnagar during year 2017 and 2018.

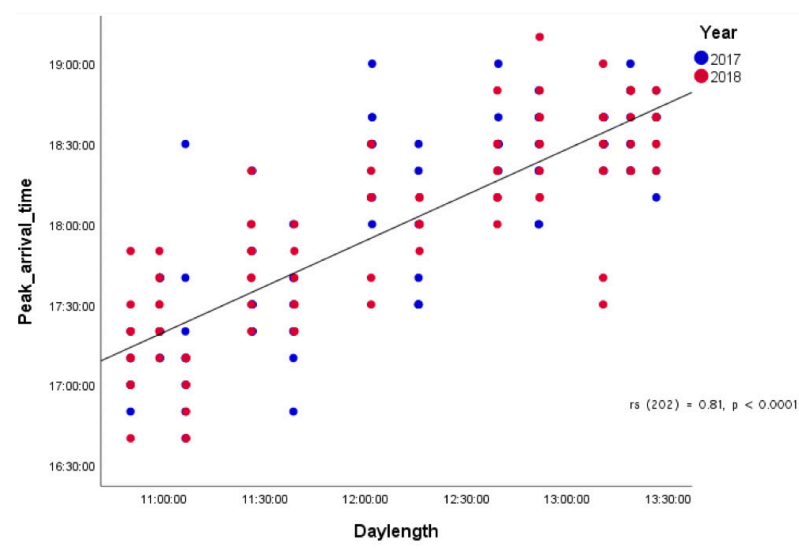

Figure 3. Correlation between peak arrival time of House Sparrow at different roosting sites and day length during study.

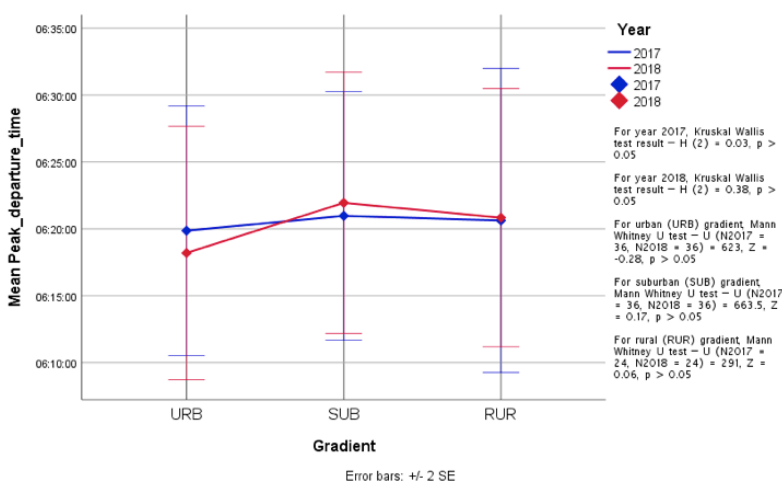

Figure 5. The mean peak departure time of House Sparrow from different roosting sites across urban (URB), suburban (SUB), and rural (RUR) gradients of Bhavnagar during year 2017 and 2018.

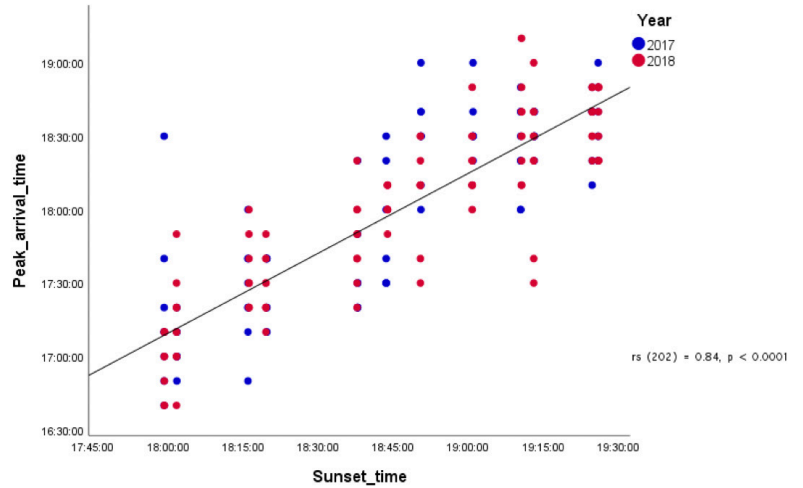

Figure 2. Correlation between peak arrival time of House Sparrows at different roosting sites and sun set time during the study.

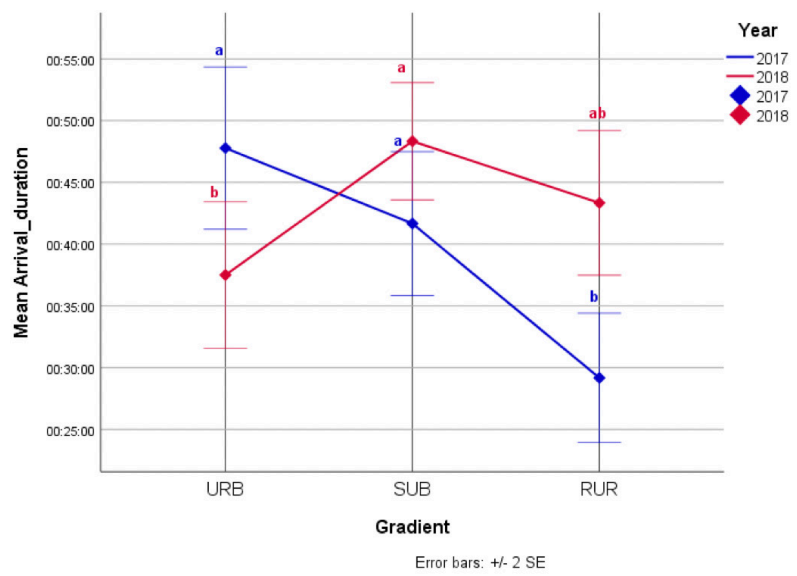

Figure 4. The mean arrival duration of House Sparrow at different sites across urban (URB), suburban (SUB) and rural (RUR) gradients of Bhavnagar during year 2017 and 2018.

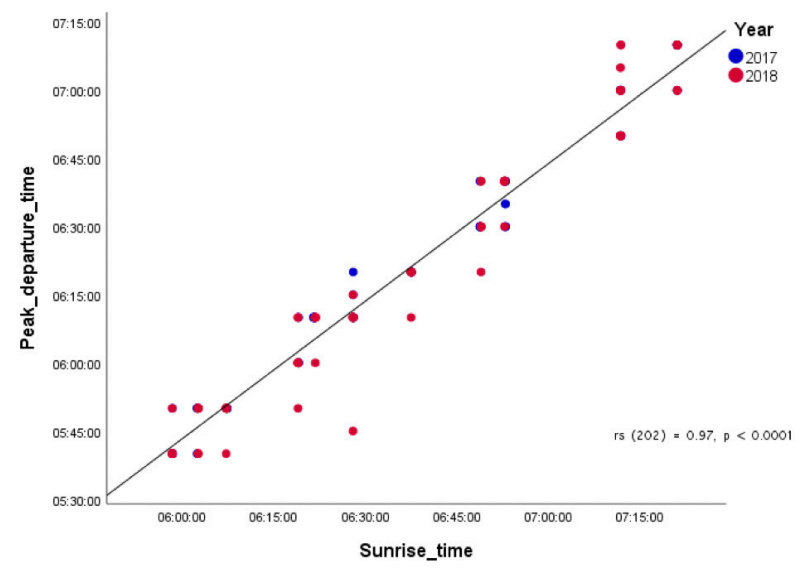

Figure 6. Correlation between peak departure time of House Sparrow from different roosting sites and sun rise time during the study. 
Table 2. The mean distance of secondary roosting plant species from original roosting plant across urban, suburban and rural gradients.

\begin{tabular}{|l|c|}
\hline Gradient & $\begin{array}{c}\text { Distance of secondary } \\
\text { roosting plants (km) }\end{array}$ \\
\hline Urban (URB) & $0.26 \pm 0.05$ \\
\hline Suburban (SUB) & $0.21 \pm 0.04$ \\
\hline Rural (RUR) & $0.17 \pm 0.04$ \\
\hline Total & $0.22 \pm 0.03$ \\
\hline
\end{tabular}

suburban gradients (Figure 4). Besides, arrival duration varied significantly across the different seasons. Usually, maximum arrival duration was recorded during monsoon and post-monsoon seasons in the current study. House Sparrows presumably spent more time in foraging due to favourable feeding conditions during these seasons, consequently frequent back and forth movements from foraging ground to roosting sites increased arrival duration.

No significant statistical difference was found in mean peak departure time across urban, suburban and rural gradients for both the years (Figure 5). There was a strong positive correlation found between peak departure time and sunrise time, which was statistically significant, $r_{s}(202)=0.977, p<0.0001$ (Figure 6). No significant statistical difference was found in mean departure duration across urban, suburban and rural gradients for both years (Figure 7).

The roosting sound started when House sparrows entered into roosting sites and lasted up to the end of nautical twilight. The roosting sound sometimes was interrupted by warning calls resulting in a sudden silence for a fraction of a minute. However, the roosting sound restarted immediately on reoccurrence of favorable conditions. It was observed that unlike the arrival pattern of sparrows, within $\mathbf{3 0}$ mins after sunrise, almost the maximum number departed together. Mostly departure occurred in the same direction from where flocks of House sparrows had arrived at the roosting site. Vocalization in the morning generally started during the nautical phase of sunrise and lasted up to approximately 10-15 min after the start of civil twilight. Further, it was observed that the House sparrow easily shares its roosting place with small passerine birds, these individuals may be of the same or different genus, i.e., heterospecific communal roosting.

Under certain circumstances, such as removal of roosting plant species or trimming of corresponding species locally, reduction in foliage density of roosting plants, presence of larger avian species at roost sites, House sparrows often change their roosting sites and opt

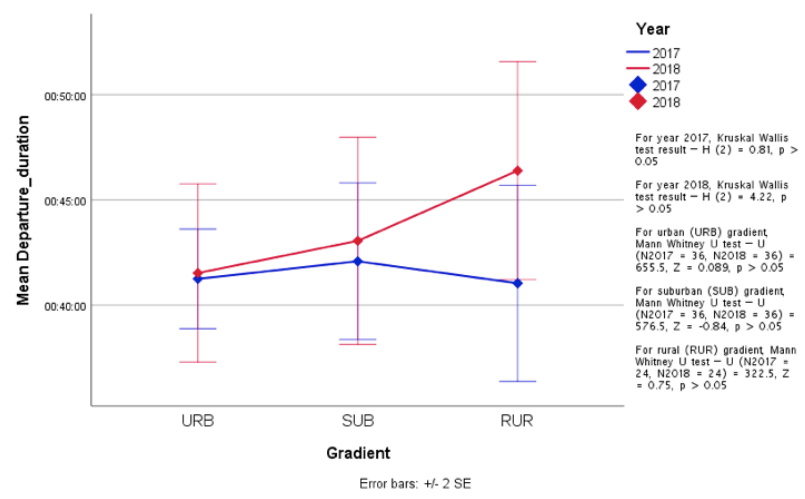

Figure 7. The mean departure time of House Sparrow across urban (URB), suburban (SUB), and rural (RUR) gradients of Bhavnagar during year 2017 and 2018.

for other suitable patches, generally found at a distance of $0.22 \pm 0.03 \mathrm{~km}$ within the study sites. However, due to restricted availability of suitable patches within urban and suburban gradients, the distance of secondary roosting plants $(0.26 \pm 0.05 \mathrm{~km}$ and $0.21 \pm 0.04 \mathrm{~km})$ was relatively higher than in rural gradient $(0.17 \pm 0.04 \mathrm{~km})$ (Table 2).

\section{DISCUSSION}

It was observed during the study that House sparrows mostly prefer to roost in dense bushy vegetation rather than in a tree with dense canopy. According to North (1968), tree height and the density of the foliage, rather than species of the plant are principle criteria for the selection of roosting sites. It was observed that often due to small disturbances sparrows opted for other suitable patches of plants found within the study sites for roosting purpose either temporarily or permanently. However, with the recurrence of favourable conditions part of the population returned to the primary roosting sites. Anderson (2006) opined that sparrows often change roosting sites if sites have less density of foliage. Preroosting gathering was also significant at all study sites. Under certain circumstances such as disturbance due to predators at the roosting sites, pre-roosting sites played an important role by providing temporarily better shelter to sparrows. In addition, various maintenance activities such as sand baths, preening, rubbing bills, and fluffing were significant during pre-roosting at all sites (Image 3B). Simmons (1964) considered preening as an essential and significant act performed by birds to maintain their feathers. For removing parasites, birds often shake their body or fluff their feathers. In the current study, sparrows 


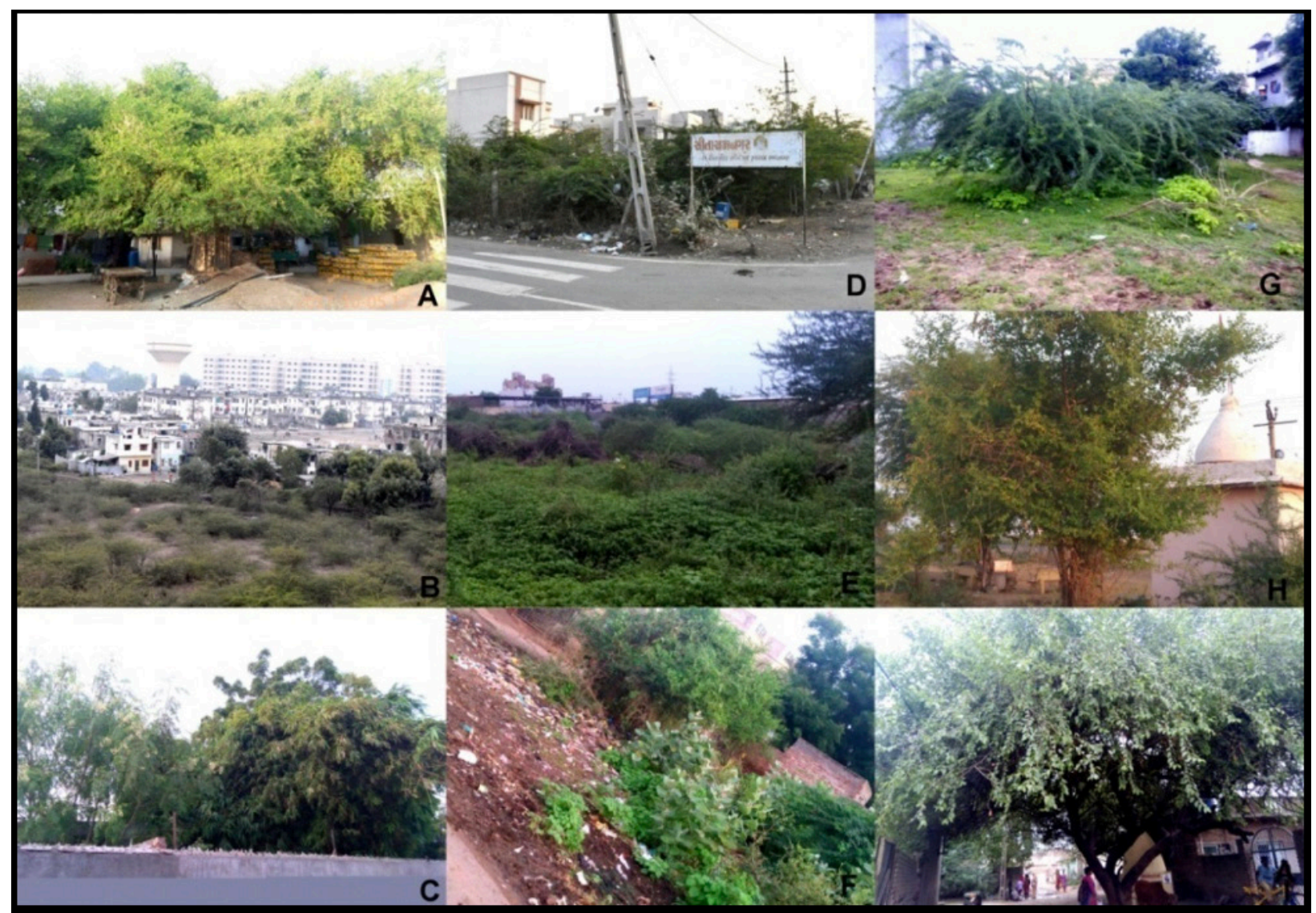

Image 2. Roosting sites of House Sparrows across different study sites: A-Barsomahadev (URB1) | B-Bharatnagar (URB2) | C-Anandnagar (URB3) | D-V P Society (SUB1) | E-Forest colony (SUB2) | F- Fulsar (SUB3) | G-Akwada (RUR1) | H-Nari (RUR2) | I-Sidsar (RUR3). (c) Foram P. Patel.

were found to preen their feathers regularly and it was significant during pre-roosting visits. Sand bath was also significant in the House sparrow population at the study area. Many studies have explained the importance of sand/dust bath by birds for removal of parasites, besides the sand bath is also essential as excess amounts of oil that birds daily preen on to their feathers to stay warm and fly is absorbed (Borchelt 1972). This stresses the importance of such characteristic habitats (e.g., sandy surface), where sparrows can efficiently perform various maintenance activities required for a healthy, sustainable life.

It was observed that sparrows arrived at their corresponding roosting sites $1-1.5 \mathrm{~h}$ before sunset. This was very similar to Anderson's (2006) observation, where he noted the arrival of sparrows at the roosting site two hours before sunset. No statistical significant difference was found in peak arrival times across different sites of each gradient between 2017 and 2018. However, peak arrival time was strongly correlated with sunset time, this indicated that the arrival of the House sparrows at the roosting site is totally influenced by photoperiod. However, presumably, various factors such as illumination (direct sun light), presence of raptors, and other larger avian species at the roosting site might play an important role in delaying arrival time at roosting sites. Variances in arrival duration of sparrows at roosting sites across urban, suburban and rural gradient could be explained as birds spent more time for last moment foraging. Statistically significant larger arrival duration in urban and suburban gradient was due to prevalence of restricted suitable patches across such gradients, where birds could spend more time for foraging. In 2018, the amount of suitable patches was significantly reduced at suburban sites such as V P Society (SUB1) and Forest colony (SUB2). Sometimes attacks by raptors such as Shikra Accipiter badius on sparrows during arrival at roosting sites made a pause in the arrival and increased the arrival duration. The peak departure time and departure duration of sparrows from roosting sites did not vary significantly across urban, suburban and rural gradients during the study period. In the evening, 


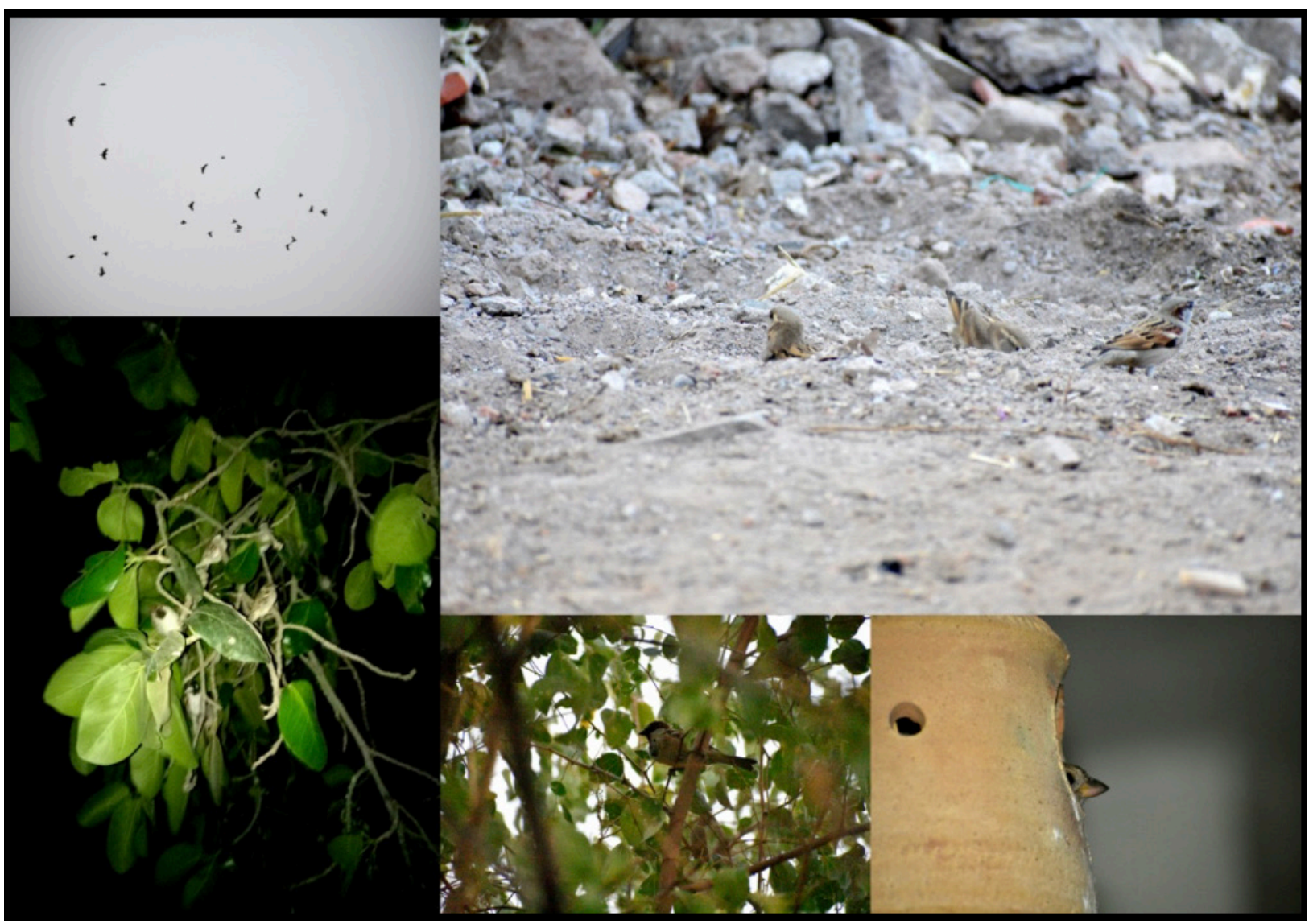

Image 3. Pre-roosting activities and roosting of House Sparrows: A-Collective motion of House Sparrow (during arrival at roost site) | BHouse Sparrows taking sand bath | C-Roosting House Sparrows | D-House Sparrows at roosting plant | E-Roost nest. $\left(C_{\text {A }}\right.$ A-C-Foram P. Patel | D-E-Kajal R. Tadha.

the roosting vocalization of sparrows was distinct and significant at all sites through which communal roosting sites of sparrows could be located from a distance. However, sometimes on warning calls, the roosting sound was interrupted for a fraction of time which began again on the return of favourable conditions. Daanje (1941) reported that House Sparrows have social warning calls through which the whole colony quickly learns of the presence of an enemy in the vicinity.

It was observed that the departure of sparrows from different roosting sites started by sunrise; $0.5 \mathrm{~h}$ to $1 \mathrm{~h}$ after sunrise a maximum number of sparrows departed from roosting sites. Departure duration recorded in the current study was a bit longer than recorded by North (1968). However, peak departure occurred within 30 min after sunrise during the current study too. It was observed that unlike the arrival pattern of sparrows, within 30 min after sunrise, almost the maximum number of the population departed together. Mostly departure occurred in the same direction from where the flocks of sparrows arrived at the roosting site. North (1968) noted the beginning of vocalization of the sparrows about 30 min before sunrise, and they usually departed from the roost within $30 \mathrm{~min}$ after sunrise. These observations of North (1968) are also supported by the current study where during the nautical phase of sunrise vocalization started and lasted up to approximately 10-15 min after the start of civil twilight.

Heterospecific communal roosting was witnessed in the current study too, where House sparrows roosted with other small passerine birds on the same roosting plant. Heterospecific communal roosts of House sparrows with different avian species are reported across the globe. House sparrows were found to share roosting sites with European Starlings in Poland (Gorska 1975), with Spanish Sparrows in Spain (Alonso 1986), with European Starlings and Eurasian Tree Sparrows in North America (North 1968; Anderson 2006). In India, Rana (1989) observed communal roosts of House sparrows with Jungle Babblers Turdoides striatus and Common Mynas Acridotheres tristis. The above mentioned study supports the observation of the current study, where a 
communal roost of House Sparrows has been observed with Large Grey Babbler Turdoides malcolmi, however, a record of sharing roosting sites with Common Myna Acridotheres tristis was lacking in the current study. Mahabal \& Bastawade (1985) reported communal roosting of House sparrows near the communal roosting site of the Black Kite (Milvus migrans govinda). However, it was observed in the current study, that the presence of larger avian species such as Alexandrine Parakeet Psittacula eupatria forced House sparrows to roost on other plant species. Further, the opportunistic presence of larger avian species at the study site also influenced House Sparrows' behavioral patterns. Like, when Painted Stork Mycteria leucocephala was present at roosting sites-for collecting corresponding nest materials from the site-sparrows swiftly entered the roosting plant, without murmuration and without producing any roosting calls, thus indicating that larger avian species negatively influence roosting House Sparrows.

\section{CONCLUSION}

During the study, peak arrival and peak departure times of the House Sparrow did not vary significantly across urban, suburban and rural gradients of Bhavnagar. While arrival duration was significantly larger in urban and suburban gradients, such variation in the arrival duration could be explained by multiple factors such as restricted availability of suitable patches, lack of suitable foraging grounds near roost sites, and the presence of raptor birds. In the present study, dense bushy vegetation was found to be the most preferred habitat of the House sparrow for roosting and pre roosting purposes across urban, suburban and rural gradients of Bhavnagar. Besides providing better night shelter, bushy vegetation forms an ideal habitat with reference to maintenance activities of the House Sparrow such as sand baths. During the study it was observed that bushy vegetation was significantly reduced across urban and suburban sites which resulted in a drastic reduction of suitable habitat patches for the House Sparrow. Hence, conservative initiatives should not be restricted to complement nesting opportunities by providing artificial nest sites, but attention should also be given to preserving suitable habitats required for the species.

\section{REFERENCES}

Alonso, J.C. (1986). Ecological segregation between sympatric Spanish Sparrows (Passer hispaniolensis Temm.) and House Sparrows (Passer domesticus [L.]) during winter. Ekologia Polska 34: 63-73.

Anderson, T. (2006). Biology of the Ubiquitous House Sparrow: From Genes to Populations. Oxford University Press, New York. https:// doi.org/10.1093/acprof:oso/9780195304114.001.0001

Beauchamp, G. (1999). The evolution of communal roosting in birds: origin and secondary losses. Behavioral Ecology 10(6): 675-687. https://doi.org/10.1093/beheco/10.6.675

Blanco, G. \& J.L. Tella (1999). Temporal, spatial and social segregation of red-billed choughs between two types of communal roost: a role for mating and territory acquisition. Animal Behaviour 57 (6): 12191227. https://doi.org/10.1006/anbe.1999.1103.PMID10373254. S2CID7254376

Borchelt, P.L. (1972). Dust bathing in Bobwhite Quail (Colinus virginianus): A regulatory model. PhD Thesis, Michigan State University.

Daanje, A. (1941). Uber der Verhalten des Haussperlings (Passer $d$. domesticus [L.]). Ardea 50: 1-42.

Ehrlich, P.R., D.S. Dobkin \& D. Wheye (1988). Communal roosting. Accessed on 10/02/2019. https://web.stanford.edu/group/ stanfordbirds/text/essays/Communal_Roosting.html

Eiserer, L.A. (1984). Communal roosting in birds. Bird Behavior 5(2-3): 61-80.

Erwin, R.M. (1983). Feeding habitats of nesting wading birds: spatial use and social influences. Auk 100: 960-970.

Gokula, V., S. Palanivel \& B. Sivagamy (2014) Nesting ecology of house sparrow Passer domesticus (Linnaeus 1758) in Punavasipatty and Kuthoor, Tamil Nadu, India. Journal of Scientific Transactions in Environment and Technovation 7(4): 193-200

Gorska, E. (1975). The investigations on the common roostings of the sparrow, Passer domesticus (L.) and starling, Sturnus vulgaris L. in Poznan in winters $1970 / 71$ and $1971 / 72$. Przeglad Zoologiczny 19: 230-238.

Gulati, V. (2005). House Sparrow on Verge of Extinction, Tribune News Service, Chandigarh. Accessed on 30.ix.2013.

Mahabal, A. \& D.B. Bastawade (1985). Population ecology and communal roosting behaviour of pariah kite Milvus migrans govinda in Pune (Maharashtra). Journal of the Bombay Natural History Society 82: 337-346.

North, C.A. (1968). A study of house sparrow populations and their movements in the vicinity of Stillwater, Oklahoma. PhD Thesis. Oklahoma State University, Stillwater.

Rana, B.D. (1989). Population ecology of Passer domesticus in the Indian arid zone. International Studies on Sparrows 16: 1-7.

Richner, H. \& P. Heeb (1996). Communal life: Honest signaling and the recruitment center hypothesis. Behavioral Ecology 7(1): 115-118. https://doi.org/10.1093/beheco/7.1.115

Simmons, K.E.L. (1964). Feather maintenance, pp. 101-105. In: Campbell B. \& E. Lack (eds.). A New Dictionary of Birds. Buteo Books, Vermillion, South Dakota.

Summers-Smith, J.D. (1988). The Sparrows. T. \& A.D. Poyser, Calton, UK.

Ward, P. \& A. Zahavi (1973). The important of certain assemblages of birds as "Information Centers" for food-feeding. Ibis 115: 517-534.

Ydenberg, R.C. \& H.H.T. Prins (1984). Why do birds roost communally in winter? Pp. 123-139. In: Evans, P.R., J.D.G. Custard \& W.G. Hale (eds.). Coastal Waders and Wildfowl in Winter. Cambridge University Press, Cambridge. 

Dr. John Noyes, Natural History Museum, London, UK

Dr. Albert G. Orr, Griffith University, Nathan, Australia

Dr. Sameer Padhye, Katholieke Universiteit Leuven, Belgium

Dr. Nancy van der Poorten, Toronto, Canada

Dr. Kareen Schnabel, NIWA, Wellington, New Zealand

Dr. R.M. Sharma, (Retd.) Scientist, Zoological Survey of India, Pune, India

Dr. Manju Siliwal, WILD, Coimbatore, Tamil Nadu, India

Dr. G.P. Sinha, Botanical Survey of India, Allahabad, India

Dr. K.A. Subramanian, Zoological Survey of India, New Alipore, Kolkata, India

Dr. P.M. Sureshan, Zoological Survey of India, Kozhikode, Kerala, India

Dr. R. Varatharajan, Manipur University, Imphal, Manipur, India

Dr. Eduard Vives, Museu de Ciències Naturals de Barcelona, Terrassa, Spain

Dr. James Young, Hong Kong Lepidopterists' Society, Hong Kong

Dr. R. Sundararaj, Institute of Wood Science \& Technology, Bengaluru, India

Dr. M. Nithyanandan, Environmental Department, La Ala Al Kuwait Real Estate. Co. K.S.C.,

Kuwait

Dr. Himender Bharti, Punjabi University, Punjab, India

Mr. Purnendu Roy, London, UK

Dr. Saito Motoki, The Butterfly Society of Japan, Tokyo, Japan

Dr. Sanjay Sondhi, TITLI TRUST, Kalpavriksh, Dehradun, India

Dr. Nguyen Thi Phuong Lien, Vietnam Academy of Science and Technology, Hanoi, Vietnam

Dr. Nitin Kulkarni, Tropical Research Institute, Jabalpur, India

Dr. Robin Wen Jiang Ngiam, National Parks Board, Singapore

Dr. Lional Monod, Natural History Museum of Geneva, Genève, Switzerland.

Dr. Asheesh Shivam, Nehru Gram Bharti University, Allahabad, India

Dr. Rosana Moreira da Rocha, Universidade Federal do Paraná, Curitiba, Brasi

Dr. Kurt R. Arnold, North Dakota State University, Saxony, Germany

Dr. James M. Carpenter, American Museum of Natural History, New York, USA

Dr. David M. Claborn, Missouri State University, Springfield, USA

Dr. Kareen Schnabel, Marine Biologist, Wellington, New Zealand

Dr. Amazonas Chagas Júnior, Universidade Federal de Mato Grosso, Cuiabá, Brasil

Mr. Monsoon Jyoti Gogoi, Assam University, Silchar, Assam, India

Dr. Heo Chong Chin, Universiti Teknologi MARA (UiTM), Selangor, Malaysia

Dr. R.J. Shiel, University of Adelaide, SA 5005, Australia

Dr. Siddharth Kulkarni, The George Washington University, Washington, USA

Dr. Priyadarsanan Dharma Rajan, ATREE, Bengaluru, India

Dr. Phil Alderslade, CSIRO Marine And Atmospheric Research, Hobart, Australia

Dr. John E.N. Veron, Coral Reef Research, Townsville, Australia

Dr. Daniel Whitmore, State Museum of Natural History Stuttgart, Rosenstein, Germany.

Dr. Yu-Feng Hsu, National Taiwan Normal University, Taipei City, Taiwan

Dr. Keith V. Wolfe, Antioch, California, USA

Dr. Siddharth Kulkarni, The Hormiga Lab, The George Washington University, Washington,

D.C., USA

Dr. Tomas Ditrich, Faculty of Education, University of South Bohemia in Ceske

Budejovice, Czech Republic

Dr. Mihaly Foldvari, Natural History Museum, University of Oslo, Norway

Dr. V.P. Uniyal, Wildlife Institute of India, Dehradun, Uttarakhand 248001, India

Dr. John T.D. Caleb, Zoological Survey of India, Kolkata, West Bengal, India

Dr. Priyadarsanan Dharma Rajan, Ashoka Trust for Research in Ecology and the Environment

(ATREE), Royal Enclave, Bangalore, Karnataka, India

\section{Fishes}

Dr. Neelesh Dahanukar, IISER, Pune, Maharashtra, India

Dr. Topiltzin Contreras MacBeath, Universidad Autónoma del estado de Morelos, México

Dr. Heok Hee Ng, National University of Singapore, Science Drive, Singapore

Dr. Rajeev Raghavan, St. Albert's College, Kochi, Kerala, India

Dr. Robert D. Sluka, Chiltern Gateway Project, A Rocha UK, Southall, Middlesex, UK

Dr. E. Vivekanandan, Central Marine Fisheries Research Institute, Chennai, India

Dr. Davor Zanella, University of Zagreb, Zagreb, Croatia

Dr. A. Biju Kumar, University of Kerala, Thiruvananthapuram, Kerala, India

Dr. Akhilesh K.V., ICAR-Central Marine Fisheries Research Institute, Mumbai Research

Centre, Mumbai, Maharashtra, India

Dr. J.A. Johnson, Wildlife Institute of India, Dehradun, Uttarakhand, India

Amphibians

Dr. Sushil K. Dutta, Indian Institute of Science, Bengaluru, Karnataka, India

Dr. Annemarie Ohler, Muséum national d'Histoire naturelle, Paris, France

\section{Reptiles}

Dr. Gernot Vogel, Heidelberg, Germany

Dr. Raju Vyas, Vadodara, Gujarat, India

Dr. Pritpal S. Soorae, Environment Agency, Abu Dubai, UAE.

Prof. Dr. Wayne J. Fuller, Near East University, Mersin, Turkey

Prof. Chandrashekher U. Rivonker, Goa University, Taleigao Plateau, Goa. India

Dr. S.R. Ganesh, Chennai Snake Park, Chennai, Tamil Nadu, India

Dr. Himansu Sekhar Das, Terrestrial \& Marine Biodiversity, Abu Dhabi, UAE
Birds

Dr. Hem Sagar Baral, Charles Sturt University, NSW Australia

Dr. Chris Bowden, Royal Society for the Protection of Birds, Sandy, UK

Dr. Priya Davidar, Pondicherry University, Kalapet, Puducherry, India

Dr. J.W. Duckworth, IUCN SSC, Bath, UK

Dr. Rajah Jayapal, SACON, Coimbatore, Tamil Nadu, India

Dr. Rajiv S. Kalsi, M.L.N. College, Yamuna Nagar, Haryana, India

Dr. V. Santharam, Rishi Valley Education Centre, Chittoor Dt., Andhra Pradesh, India

Dr. S. Balachandran, Bombay Natural History Society, Mumbai, India

Mr. J. Praveen, Bengaluru, India

Dr. C. Srinivasulu, Osmania University, Hyderabad, India

Dr. K.S. Gopi Sundar, International Crane Foundation, Baraboo, USA

Dr. Gombobaatar Sundev, Professor of Ornithology, Ulaanbaatar, Mongolia

Prof. Reuven Yosef, International Birding \& Research Centre, Eilat, Israel

Dr. Taej Mundkur, Wetlands International, Wageningen, The Netherlands

Dr. Carol Inskipp, Bishop Auckland Co., Durham, UK

Dr. Tim Inskipp, Bishop Auckland Co, Durham, UK

Dr. V. Gokula, National College, Tiruchirappalli, Tamil Nadu, India

Dr. Arkady Lelej, Russian Academy of Sciences, Vladivostok, Russia

Dr. Simon Dowell, Science Director, Chester Zoo, UK

Dr. Mário Gabriel Santiago dos Santos, Universidade de Trás-os-Montes e Alto Douro,

Quinta de Prados, Vila Real, Portugal

Dr. Grant Connette, Smithsonian Institution, Royal, VA, USA

Dr. M. Zafar-ul Islam, Prince Saud Al Faisal Wildlife Research Center, Taif, Saudi Arabia

Mammals

Dr. Giovanni Amori, CNR - Institute of Ecosystem Studies, Rome, Italy

Dr. Anwaruddin Chowdhury, Guwahati, India

Dr. David Mallon, Zoological Society of London, UK

Dr. Shomita Mukherjee, SACON, Coimbatore, Tamil Nadu, India

Dr. Angie Appel, Wild Cat Network, Germany

Dr. P.O. Nameer, Kerala Agricultural University, Thrissur, Kerala, India

Dr. Ian Redmond, UNEP Convention on Migratory Species, Lansdown, UK

Dr. Heidi S. Riddle, Riddle's Elephant and Wildlife Sanctuary, Arkansas, USA

Dr. Karin Schwartz, George Mason University, Fairfax, Virginia.

Dr. Lala A.K. Singh, Bhubaneswar, Orissa, India

Dr. Mewa Singh, Mysore University, Mysore, India

Dr. Paul Racey, University of Exeter, Devon, UK

Dr. Honnavalli N. Kumara, SACON, Anaikatty P.O., Coimbatore, Tamil Nadu, India

Dr. Nishith Dharaiya, HNG University, Patan, Gujarat, India

Dr. Spartaco Gippoliti, Socio Onorario Società Italiana per la Storia della Fauna "Giuseppe

Altobello", Rome, Italy

Dr. Justus Joshua, Green Future Foundation, Tiruchirapalli, Tamil Nadu, India

Dr. H. Raghuram, The American College, Madurai, Tamil Nadu, India

Dr. Paul Bates, Harison Institute, Kent, UK

Dr. Jim Sanderson, Small Wild Cat Conservation Foundation, Hartford, USA

Dr. Dan Challender, University of Kent, Canterbury, UK

Dr. David Mallon, Manchester Metropolitan University, Derbyshire, UK

Dr. Brian L. Cypher, California State University-Stanislaus, Bakersfield, CA

Dr. S.S. Talmale, Zoological Survey of India, Pune, Maharashtra, India

Prof. Karan Bahadur Shah, Budhanilakantha Municipality, Kathmandu, Nepal

Dr. Susan Cheyne, Borneo Nature Foundation International, Palangkaraja, Indonesia

Dr. Hemanta Kafley, Wildlife Sciences, Tarleton State University, Texas, USA

\section{Other Disciplines}

Dr. Aniruddha Belsare, Columbia MO 65203, USA (Veterinary)

Dr. Mandar S. Paingankar, University of Pune, Pune, Maharashtra, India (Molecular)

Dr. Jack Tordoff, Critical Ecosystem Partnership Fund, Arlington, USA (Communities)

Dr. Ulrike Streicher, University of Oregon, Eugene, USA (Veterinary)

Dr. Hari Balasubramanian, EcoAdvisors, Nova Scotia, Canada (Communities)

Dr. Rayanna Hellem Santos Bezerra, Universidade Federal de Sergipe, São Cristóvão, Brazil

Dr. Jamie R. Wood, Landcare Research, Canterbury, New Zealand

Dr. Wendy Collinson-Jonker, Endangered Wildlife Trust, Gauteng, South Africa

Dr. Rajeshkumar G. Jani, Anand Agricultural University, Anand, Gujarat, India

Dr. O.N. Tiwari, Senior Scientist, ICAR-Indian Agricultural Research Institute (IARI), New

Delhi, India

Dr. L.D. Singla, Guru Angad Dev Veterinary and Animal Sciences University, Ludhiana, India

Dr. Rupika S. Rajakaruna, University of Peradeniya, Peradeniya, Sri Lanka

Dr. Bahar Baviskar, Wild-CER, Nagpur, Maharashtra 440013, India

Reviewers 2018-2020

Due to pausity of space, the list of reviewers for $2018-2020$ is available online.

The opinions expressed by the authors do not reflect the views of the Journal of Threatened Taxa, Wildlife Information Liaison Development Society, Zoo Outreach Organization, or any of the partners. The journal, the publisher, the host, and the partners are not responsible for the accuracy of the political boundaries shown in the maps by the authors.

Journal of Threatened Taxa is indexed/abstracted in Bibliography of Systematic Mycology, Biological Abstracts, BIOSIS Previews, CAB Abstracts, EBSCO, Google Scholar, Index Copernicus, Index Fungorum, JournalSeek, National Academy of Agricultural Sciences, NewJour, OCLC WorldCat, SCOPUS, Stanford University Libraries, Virtual Library of Biology, Zoological Records.

NAAS rating (India) 5.64
Print copies of the Journal are available at cost. Write to:

The Managing Editor, JoTT,

c/o Wildlife Information Liaison Development Society,

No. 12, Thiruvannamalai Nagar, Saravanampatti - Kalapatti Road,

Saravanampatti, Coimbatore, Tamil Nadu 641035, India

ravi@threatenedtaxa.org 


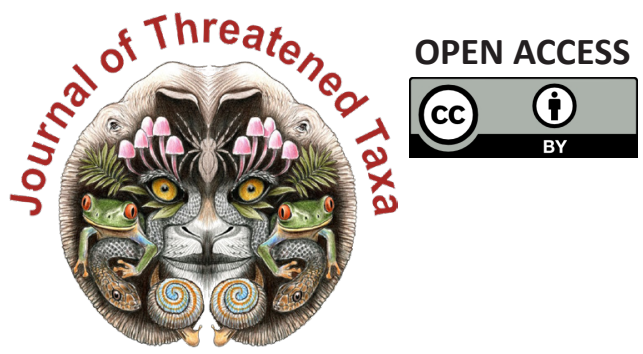

www.threatenedtaxa.org

The Journal of Threatened Taxa (JoTT) is dedicated to building evidence for conservation globally by publishing peer-reviewed articles online every month at a reasonably rapid rate at www.threatenedtaxa.org. All articles published in JoTT are registered under Creative Commons Attribution 4.0 International License unless otherwise mentioned. JoTT allows allows unrestricted use, reproduction, and distribution of articles in any medium by providing adequate credit to the author(s) and the source of publication.

\section{ISSN $0974-7907$ (Online) | ISSN $0974-7893$ (Print)}

\section{December 2021 | Vol. 13 | No. 14 | Pages: 20143-20310 \\ Date of Publication: 26 December 2021 (Online \& Print) DOI: 10.11609/jott.2021.13.14.20143-20310}

\section{Communications}

Updated distribution of seven Trichosanthes L. (Cucurbitales: Cucurbitaceae) taxa in India, along with taxonomic notes

Kanakasabapathi Pradheep, Soyimchiten, Ganjalagatta Dasaiah Harish, Muhammed Abdul Nizar, Kailash Chandra Bhatt, Anjula Pandey \& Sudhir Pal Ahlawat, Pp. 20143-20152

Dragonflies and Damselflies (Insecta: Odonata) of Aryanad Grama Panchayat, Kerala, India

- Reji Chandran \& A. Vivek Chandran, Pp. 20153-20166

Checklist of Odonata (Insecta) of Doon Valley, Uttarakhand, India

- Kritish De, Sarika Bhatt, Amar Paul Singh, Manisha Uniyal \& Virendra Prasad Uniyal, Pp. 20167-20173

Diversity of moths from the urban set-up of Valmiki Nagar, Chennai, India - Vikas Madhav Nagarajan, Rohith Srinivasan \& Mahathi Narayanaswamy, Pp. 20174-20189

Ichthyofaunal diversity with relation to environmental variables in the snowfed Tamor River of eastern Nepal

- Jawan Tumbahangfe, Jash Hang Limbu, Archana Prasad, Bhrarat Raj Subba \& Dil Kumar Limbu, Pp. 20190-20200

Observations on the foraging behavior of Tricoloured Munia Lonchura malacca (Linnaeus, 1766) and its interaction with pearl millet fields in Villupuram District, Tamil Nadu, India

- M. Pandian, Pp. 20201-20208

Roosting patterns of House Sparrow Passer domesticus Linn., 1758 (Aves: Passeridae) in Bhavnagar, Gujarat, India

- Foram P. Patel \& Pravinsang P. Dodia, Pp. 20209-20217

Review

Comprehensive checklist of algal class Chlorophyceae (sensu Fritsch, 1935) for Uttar Pradesh, India, with updated taxonomic status

- Sushma Verma, Kiran Toppo \& Sanjeeva Nayaka, Pp. 20218-20248

\section{View Point}

Wildlife managers ignore previous knowledge at great risk: the case of Rivaldo, the iconic wild Asian Elephant Elephas maximus L. of the Sigur Region, Nilgiri Biosphere Reserve, India

- Jean-Philippe Puyravaud \& Priya Davidar, Pp. 20249-20252

\section{Short Communications}

Diversity and distribution of macro lichens from Kalpetta Municipality of Wayanad District, Kerala, India

- Greeshma Balu, A.R. Rasmi, Stephen Sequeira \& Biju Haridas, Pp. 20253-20257

Extended distribution of two endemic epiphytes from the Western Ghats to the Deccan Plateau

- Sonali Vishnu Deore, Mangala Dala Sonawane \& Sharad Suresh Kambale, Pp. 20258-20260

Nomenclatural notes and report of Boehmeria penduliflora Wedd. ex D.G. Long from the Terai region of Uttar Pradesh, India

- Amit Gupta, Imtiyaz Ahmad Hurrah, Aparna Shukla \& Vijay V. Wagh, Pp. 2026120265
New distribution record of a true coral species, Psammocora contigua (Esper, 1794) from Gulf of Kachchh Marine National Park \& Sanctuary, India - R. Chandran, R. Senthil Kumaran, D.T. Vasavada, N.N. Joshi \& Osman G. Husen, Pp. 20266-20271

A new species of flat-headed mayfly Afronurus meenmutti (Ephemeroptera: Heptageniidae: Ecdyonurinae) from Kerala, India

- Marimuthu Muthukatturaja \& Chellaiah Balasubramanian, Pp. 20272-20277

Photographic record of Dholes predating on a young Banteng in southwestern Java, Indonesia

- Dede Aulia Rahman, Mochamad Syamsudin, Asep Yayus Firdaus, Herry Trisna Afriandi \& Anggodo, Pp. 20278-20283

Latrine site and its use pattern by Large Indian Civet Viverra zibetha Linnaeus, 1758: record from camera trap

- Bhuwan Singh Bist, Prashant Ghimire, Basant Sharma, Chiranjeevi Khanal \& Anoj Subedi, Pp. 20284-20287

Notes

Two additions to the flora of Kerala, India

- P. Murugan, Basil Paul \& M. Sulaiman, Pp. 20288-20291

Pentatropis R.Br. ex Wight \& Arn. (Apocynaceae), a new generic record for Kerala, India

- V. Ambika, Jose Sojan \& V. Suresh, Pp. 20292-20294

New record of Kashmir Birch Mouse Sicista concolor leathemi (Thomas, 1893) (Rodentia: Sminthidae) in the Indian Himalaya

- S.S. Talmale, Avtar Kaur Sidhu \& Uttam Saikia, Pp. 20295-20298

Breeding record of Black-headed Ibis Threskiornis melanocephalus (Aves: Threskiornithidae) at Mavoor wetland, Kozhikode District, Kerala, India - C.T. Shifa, Pp. 20299-20301

\section{Response}

Crop and property damage caused by Purple-faced Langurs Trachypithecus vetulus (Mammalia: Primates: Cercopithecidae) - Vincent Nijman, Pp. 20302-20306

Reply

If habitat heterogeneity is effective for conservation of butterflies in urban landscapes of Delhi, India? Unethical publication based on data manipulation: Response of original authors

- Monalisa Paul \& Aisha Sultana, Pp. 20307-20308

\section{Book Review}

Freshwater fishes of the Arabian Peninsula - Rajeev Raghavan, Pp. 20309-20310

Publisher \& Host

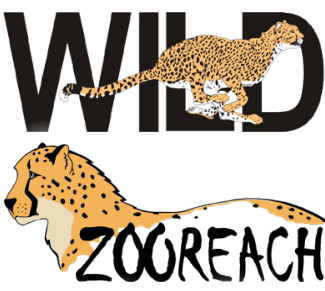

Threatened Taxa 